Board of Governors of the Federal Reserve System

International Finance Discussion Papers

Number 1042

February 2012

\title{
Monetary Policy in Emerging Market Economies: What Lessons from the Global Financial Crisis?
}

\author{
Brahima Coulibaly*
}

NOTE: International Finance Discussion Papers are preliminary materials circulated to stimulate discussion and critical comment. References to International Finance Discussion Papers (other than an acknowledgment that the writer has had access to unpublished material) should be cleared with the author or authors. Recent IFDPs are available on the Web at www.federalreserve.gov/pubs/ifdp/. This paper can be downloaded without charge from Social Science Research Network electronic library at www.ssrn.com. 


\title{
Monetary Policy in Emerging Market Economies: What Lessons from the Global Financial Crisis?
}

\author{
Brahima Coulibaly ${ }^{*}$
}

February 2012

\begin{abstract}
During the 2008-2009 global financial crisis, emerging market economies (EMEs) loosened monetary policy considerably to cushion the shock. In previous crises episodes, by contrast, EMEs generally had to tighten monetary policy to defend the value of their currencies, to contain capital flight, and to bolster policy credibility. Our study aims to understand the factors that enabled this remarkable shift in monetary policy, and also to assess whether this marks a new era in which EMEs can now conduct countercyclical policy, more in line with advanced economies. The results indicate statistically significant linkages between some characteristics of the economies and their ability to conduct countercyclical monetary policy. We find that macroeconomic fundamentals and lower vulnerabilities, openness to trade, and international capital flows, financial reforms, and the adoption of inflation targeting all facilitated the conduct of countercyclical policy. Of these factors, the most important have been the financial reforms achieved over the past decades and the adoption of inflation targeting. As long as EMEs maintain these strong economic fundamentals, continue to reform their financial sector, and adopt credible and transparent monetary policy frameworks such as inflation targeting, the conduct of countercyclical monetary policy will likely be sustainable.
\end{abstract}

Keywords: Monetary policy, crises, macroeconomic stabilization

JEL classifications: E52, E58, E63

* Senior Economist in the Division of International Finance of the Federal Reserve System. Mailing address: Division of International Finance, Board of Governors, Federal Reserve System, Mail Stop 24, Washington, DC 20551,USA; email: brahima.coulibaly@frb.gov; tel.: (202) 452-2609; fax: (202) 7365638. The author thanks Shaghil Ahmed, John Rogers, Roberto Chang, and participants of the 2nd BIS CCA Conference on "Monetary Policy, Financial Stability and the Business Cycle" for helpful comments and discussions, and Andrew Brooks and Karan Jain for outstanding research assistantship. The views in this paper are solely the responsibility of the author(s) and should not be interpreted as reflecting the views of the Board of Governors of the Federal Reserve System or of any other person associated with the Federal Reserve System. 


\section{Introduction}

During the financial crisis of 2008-2009, emerging market economies (EMEs) loosened monetary policy considerably to cushion against the global financial shock and to foster economic recovery. This is a remarkable departure from previous crisis episodes during which EMEs generally had to raise interest rates in order to bolster the credibility of monetary policy, to defend the value of their currencies, and to contain capital flight. Our study asks what factors enabled this shift in monetary policy of EMEs, and it assesses whether this shift marks a new era in which EMEs can pursue countercyclical monetary policy like their counterparts in advanced economies.

Macroeconomic policies-both fiscal and monetary-tend to be countercyclical in advanced economies. In EMEs, by contrast, these policies tend to be procyclical or, at best, acyclical that tend to be countercyclical. This feature of monetary and fiscal policy deprived EMEs of important macroeconomic stabilization tools, and might partly explain the higher volatility of output in EMEs compared with the advanced economies documented in Aguiar and Gopinath (2007) and others. One way to reduce output volatility and enhance welfare in EMEs is to understand the factors that prevented policymakers in EMEs from conducting countercyclical policy in the past, and to devise policies to help them use fiscal and monetary policy for macroeconomic stabilization.

Studies have analyzed the factors driving the cyclicality in the fiscal policy of EMEs. See for example, Gavin and Perotti (1997), Talvi and Vegh (2004), and others. ${ }^{1}$ By contrast, there are few empirical studies of the cyclicality in the monetary policy in EMEs. This sparsity likely reflects the difficulty of finding common monetary policy instruments over time and across countries, as these instruments depend importantly on the exchange rate regime. Even with common instruments, characterizing the monetary policy stance is difficult.

In Kaminsky, Reinhart, and Vegh (2004) examines cyclicality in the monetary policy of a broad set of countries covering both emerging market and advanced economies by relying primarily on short-term interest rates. Assuming imperfect substitution between domestic and foreign assets, short-term interest rates can represent common monetary policy instruments under both flexible and predetermined exchange rate regimes. Using these short-term interest rates, Kaminsky et al. (2004) estimate a Taylor rule policy function for each country and find that monetary policy is generally countercyclical in advanced economies. By contrast, it tends to be procyclical in EMEs.

\footnotetext{
${ }^{1}$ Including, Braun (2001), Lane (2003), Gupta et al. (2004), Riascos and Vegh (2003), Kaminsky, Reinhart, and Vegh (2004), etc.
} 
Kaminsky, Reinhart, and Vegh (2004) did not explore the factors preventing EMEs from conducting countercyclical monetary policy. These factors were explored in Calderon et al. (2003) for a set of eleven EMEs. They find that the ability of these EMEs to conduct both countercyclical fiscal and monetary policies is determined by the credibility of their policies.

Our study adds to this sparse literature by examining the behavior of monetary policy during economic crises. Economic crises are costly in output and welfare losses. Optimal response to crises generally require countercyclical policies to cushion the shock and to foster economic recovery. Yet in EMEs, the crises are exacerbated by procyclical policies, including monetary policy. However, during the 2008-2009 global financial crisis, central banks in EMEs were able to loosen monetary policy considerably, perhaps signaling that monetary policy has evolved in these countries. To our knowledge, this is the first study to comprehensively assess the factors that determined the cyclicality of monetary policy during the 2008-2009 financial crisis, and during crises more generally.

We construct a large dataset for 188 advanced and emerging market countries from 1970 through 2009. We identify 1,462 financial and economic crisis years, and examine the behavior of monetary policy during those crises. The results confirm that advanced economies have historically conducted countercyclical monetary policy during crises while EMEs tended to tighten monetary policy. However, the difference in policy response between the two sets of countries has been fading. In the most recent decade, notably during the 2008-2009 crisis, EMEs have generally conducted countercyclical policy like their counterparts in the advanced economies.

Our estimation strategy uses a Logit regression model to examine the factors that have facilitated the conduct of countercyclical monetary policy in EMEs. The results indicate statistically significant linkages between some characteristics of the economies and policymakers' ability to conduct countercyclical monetary policy. We find that while stronger macroeconomic fundamentals, reduced vulnerabilities, greater openness to trade and international capital flows facilitated the conduct of countercyclical policy, the most important determinants have been the financial reforms achieved over the past decades and the adoption of inflation targeting. Inflation targeting regimes, which are becoming more pervasive among EMEs, enhance greater policy transparency and flexibility of monetary policy. EMEs also achieve greater policy credibility by adopting inflation targeting regimes and by achieving greater financial reforms. As long as EMEs maintain strong economic fundamentals, continue to reform their financial markets, and adopt credible and transparent mon- 
etary policy frameworks such as inflation targeting, the conduct of countercyclical policy as an economic stabilization tool might be sustainable.

The remainder of the paper is organized as follows: In the next section, we discuss some of the literature on the determinants of monetary policy stance in EMEs. Sections 4 and 5 describe the econometric strategy, the data, and the results. Section 5 is devoted to caveats and robustness analyses, and we offer concluding remarks in Section 6 .

\section{Determinants of Monetary Policy in Emerging Market Economies During Crises}

During economic crises the common policy prescription is to loosen monetary policy in order to support domestic economic activity. This prescription is theoretically motivated by the Keynesian models and illustrated in practice by the Taylor rule type of approach to monetary policy. In this setting, looser monetary policy is necessary to help close the negative output gap and restore full employment. The consequent increase in domestic liquidity tempers the effect of the contraction in external credit that usually occurs during EMEs' crises. Advanced economies have generally followed this practice. In EMEs, however, other factors have prevented the conduct of countercyclical policy or made countercyclical policy undesirable.

Conditional on specific economic vulnerabilities, countercyclical policy might not be optimal. For example, if a country has a large fraction of its debt that is short term and denominated in foreign currency, the adverse balance sheet effects of an exchange rate depreciation induced by a countercyclical policy could more than offset any potential costs of a procyclical policy. In this case, it would be optimal to maintain a procyclical monetary policy. Internal vulnerabilities such as these or other institutional deficiencies explain the inability or undesirability of policymakers in EMEs to conduct countercyclical policy. And authorities in these countries have often been more concerned about bolstering the credibility of policy, containing capital flight, and defending the values of their currencies.

A study by Calderon et al. (2003) of the cyclicality of monetary policy in some EMEs, finds that credibility of policy was the determining factor. As pointed out by Lane (2003), when the monetary authority lacks credibility, a temporary loosening of monetary policy is perceived as heralding a persistent switch to a loose money regime with adverse effects on confidence and increases in risk 
premiums demanded by foreign investors. ${ }^{2}$

We include in our study some variables that capture the strength of institutions and the credibility of policy: the exchange rate regime, an indicator for inflation targeting, a measure of financial reforms-the extent to which authorities have allowed market forces to determine outcomes in credit and financial markets-, and a measure of financial development.

In addition to measuring strength of institutions and the credibility of policy, the financial development variable has a unique relevance. Financial development enables a more efficient transmission of monetary policy and, hence, increases the incentives to conduct countercyclical policy. Also, the development of financial markets has traditionally promoted more borrowing on domestic markets and in local currencies. A higher share of local currency debt reduces risks of capital flight, and risks of currency and maturity mismatches. As such, development of domestic financial markets facilitates the conduct of countercyclical policy.

Devereux and Lane (2003) finds that countries with a greater dependence on foreign currency debt are more likely to tailor policy to minimize exchange rate volatility with the creditor country. Besides restricting monetary policy, dependence on external debt and debt with shorter maturities has affected the perceived solvency of EMEs during crises. With this consideration in mind, we include variables on external debt and its maturity structure and variables on the country's finances such as foreign exchange reserves and central government debt.

We also consider other macroeconomic fundamentals such as current account balances and inflation. A low inflation environment facilitates the loosening of monetary policy, consistent with the prescriptions from a Taylor rule function. Inflation could also capture the independence of the central bank and, hence, credibility of monetary policy. Several studies document that central banks in lower-inflation countries are more independent (see for example, Alesina and Summers, 1993); and central bank independence improves the efficiency of monetary policy (Mishkin, 2010).

Economic integration is also an important factor. A study by Yakhin (2008) finds that under financial integration, the optimal monetary policy is countercyclical, but procyclical under autarky. These results suggest an important role for openness. We include a measure of financial openness, and also trade openness.

In sum, the variables we explore in this study can be classified into four categories: Macroeco-

\footnotetext{
${ }^{2}$ See also Caballero (2002), Calvo and Reinhart (2002) and Mendoza (2002).
} 
nomic fundamentals and vulnerabilities, openness, monetary policy and exchange rate framework, and financial development and reforms. These variables are not independent of each other and the categories are likely not insular. In the empirical analysis, we assess the statistical link between monetary policy and these variables in both univariate and multivariate econometric frameworks.

\section{Monetary Policy in Emerging Market Economies during the 2008-2009 Financial Crisis}

In this section, we analyze monetary policy during the 2008-2009 global crisis. At the height of the crisis, between the third quarter of 2008 and the end of the first quarter of 2009, over 80 percent of EMEs loosened monetary policy. In the analysis that follows, we assess the factors that enabled most, but not all, countries to loosen monetary policy.

\subsection{Econometric Specification and Data Description}

We estimate the following Logit model using the indicator variable for countercyclical monetary policy during crises as the dependent variable:

$$
\operatorname{Pr} o b\left(C C M P_{i}=1\right)=\Phi\left(\beta^{\prime} X_{i 2007}\right)
$$

A country is considered to have conducted countercyclical monetary policy during the crisis if the cumulative change in the monetary policy rate between the third quarter of 2008 and the end of the first quarter in 2009 is negative. $C C M P_{i}$ is the indicator variable for whether country $i$ has, on net, lowered its monetary policy rate between the third quarter of 2008 and the end of the first quarter in 2009. $X$ represents the set of variables that determine the conduct of monetary policy. They are measured in in 2007- the year prior to the crisis.

Macroeconomic Fundamentals and Vulnerability: FXR2GDP and $C A B 2 G D P$ are the foreign exchange reserves and current account balance as percent of GDP, respectively. CGD2GDP is the central government debt as percent of GDP. $I N F$ is the annual change of the consumer price index. STDT2EXTDT and STDT2FXR represent short-term external debt as percent of total external debt and foreign exchange reserves, respectively.

Openness: OPENTRADE and OPENFIN capture the degree of trade and financial openness, 
respectively. Trade openness is the the sum of imports and exports as percent of GDP. For financial openness, we use the Chinn-Ito index of capital account openness. It was initially introduced in Chinn and Ito (2006) and subsequently updated by the authors through 2008. The index is based on the tabulation of binary dummy variables that capture restrictions on cross-border financial transactions as reported in the IMF's Annual Report on Exchange Arrangements and Exchange Restrictions (AREAER). It varies from -1.8 to 2.5, with higher numbers indicating greater financial openness. ${ }^{3}$

Exchange Rate Regime and Policy Credibility: IT is an indicator variable for whether the country's central bank is an inflation targeter in a given year. EXCHREG captures the rigidity of the exchange rate regime based on the classification in the IMF's AREAER. For a given year, each country is assigned a number between 1 and 5, with higher numbers indicating greater flexibility of the exchange rate regime.

Financial Development and Financial Reforms: FINDEV measures financial development based on data for bank deposit, financial system deposits, deposit banks' assets, and credit extended by banks and total credit to the domestic economy. We then divide these variables by GDP and conduct a principal component analysis to obtain a single index. The resulting factor (index) is highly correlated (0.92 or higher) with the variables, and explains 93 percent of the variability of these variables. FINREF measures financial reforms. It is an index constructed by Abiad et al. (2008) based on factors such as the extent of directed credit, level of reserve requirements, prevalence of credit controls and credit ceilings, interest rate controls, entry barriers, capital account restrictions, state ownership in banking sector, and prudential regulations and supervision of the banking sector. The index provides a number ranging from 0 to 21, with higher values indicating greater degrees of financial reform. See Abiad et al. (2008) for details. In this study, we use the normalized (between 0 and 1) version of the index, also provided by the authors. The reforms index has a high autocorrelation coefficient of 0.99 . We use an $A R(1)$ process to impute the missing values for 2006 and 2007. ${ }^{4}$ Table 1 presents summary statistics for the variables described above for the the 2008-2009 subsample.

Figures 1 through 3 plot the median or mean values of some key variables through 2007 for the set of countries that lowered their policy rates (the bold line) and the set of those that did

\footnotetext{
${ }^{3}$ See http://web.pdx.edu/ ito/Readme_kaopen2008.pdf for details.

${ }^{4}$ More specifically, our imputation model was $F I N R E F_{i t}=0.99 * F I N R E F_{i t-1}+\varepsilon_{i t}$.
} 
not (the thin line). Several of these key variables highlight the difference between the two sets of countries. Those that loosened monetary policy had better macroeconomic fundamentals and lower vulnerabilities: inflation was lower on the eve of the crisis; current account balances were in large surplus while those of countries that could not lower rates were in deficit; reserves as percent of GDP were higher, and central government debt as percent of GDP was lower. Also, compared with countries that could not lower rates, those that did had external debt with slightly longer maturities, and lower short-term debt as percent of reserves. They were also more open to trade and international capital flows, had relatively more flexible exchange rate regimes, and were more likely to be inflation targeters. Finally, countries that lowered monetary policy had more developed financial markets and had made more progress on financial reforms.

To facilitate interpretation of our regression results, we transform all of the continuous variables into categorical variables: top quartile, midquartiles, and bottom quartile. This transformation also allows for the exploration of nonlineraties and to control for the effect of potential outliers.

\subsection{Estimation and Results}

\subsubsection{Univariate Analysis}

The regression results for the univariate analysis (each regression has only one explanatory variable) are shown in Table 2. Columns 2, 3, and 4 show the logit coefficients, p-values, and odds ratios, respectively.

Macroeconomic Fundamentals and Vulnerability: These results suggest that strong macroeconomic fundamentals and reduced vulnerability in the pre-crisis year increased the chances of conducting countercyclical monetary policy. A country with pre-crisis inflation in the top quartile of the distribution has lower odds of reducing rates during the crisis. Similarly, countries with the lowest government debt and highest current account surplus (in the top quartiles) were, respectively, about 2.3 and 3.5 times more likely to conduct countercyclical policy. The coefficients for the share of short-term external debt, foreign exchange reserves as percent of GDP, and short-term debt as percent of foreign exchange reserves have the expected sign, but they are not statistically significant.

Openness: The next set of results indicates an important role for openness in a country's ability to conduct countercyclical monetary policy. Countries with highly open capital accounts (top quartile of the distribution) were 3 times more likely to loosen monetary policy during the 
2008-2009 crisis. Similarly, those most open to trade on the eve of the crisis were 2.5 times more likely to loosen monetary policy.

Exchange Rate Regime and Policy Credibility: The coefficient for the exchange rate regime has the expected sign; countries with the most flexible form of exchange rate regime are more likely to loosen monetary policy but the coefficient is not statistically significant. The results for inflation targeting, which also proxies for transparency and credibility of the central bank, are very strong. A country with an inflation targeting regime was about 7.6 times more likely to conduct countercyclical monetary policy than a country without one.

Financial Development and Financial Reforms: The result for financial reform is also very strong. It suggests that a country with the highest level of financial reform was 4.5 times more likely to loosen monetary policy. For financial development, the positive coefficient has the expected sign though it is not statistically significant.

We suspect that these variables are not necessarily independent of each other. In the next analysis, we estimate the effect of these various factors in a multivariate econometric framework.

\subsubsection{Multivariate Analysis}

Tables 3 presents the odds ratios obtained from the multivariate regression using equation (1). We estimate the model with OxMetrics, a statistical software package that explores various combinations of regressors to maximize the fit of the model based on the Akaike Information Criterion. ${ }^{5}$ At the outset, it suggested 5 alternative models-Columns (1) through (5). Overall, the results are consistent with those of the univariate analysis. Countries with the lowest level of government debt on the eve of the crisis were about 2.5 times more likely to loosen monetary policy. Those that were most open, particularly to capital flows, had greater odds of conducting countercyclical monetary policy. Inflation targeting remains the most important determinant of a country's ability to conduct countercyclical policy. The results are strong and consistently robust across various specifications.

In sum, the analysis provides evidence of links between EMEs' ability to conduct countercyclical policy during the crisis and some pre-crisis characteristics of their economies, such as level of government debt, degree of openness, and most importantly, inflation targeting monetary policy

\footnotetext{
${ }^{5}$ The model selection process is based on the set of variables that maximize the likelihood function and applies the Akaike Information Criterion.
} 
framework. This remarkable development begs the following question: Is the ability of EMEs to conduct countercyclical policy during the 2008-09 crisis ephemeral or is it a reflection of structural improvements that have enabled monetary policy to become a more effective macroeconomic stabilization tool? In the next set of analyses, we explore the determinants of countercyclical monetary policy in EMEs more generally by expanding the sample to the preceding four decades-1970 through 2009.

\section{Monetary Policy in Emerging Market Economies: Beyond the 2008-2009 Crisis}

In this section, we explore more generally the determinants of countercyclical monetary in EMEs over the past four decades.

\subsection{Identification of Crises and Monetary Policy Stance}

Two variables that are central to our study are indicators for crises and the monetary policy stance. We follow Frankel and Rose (1996) and define a crisis year as one in which the bilateral U.S. dollar exchange rate depreciated at least 25 percent, with the rate of depreciation exceeding the previous year's depreciation by at least 10 percentage points. ${ }^{6}$ In addition, we include periods with negative or zero real gross domestic product (GDP) growth in order to capture episodes of economic stress that necessitate active countercyclical monetary policy, but when exchange rate movements might not be substantial. At the outset, we obtain 1,462 episodes between 1970 and 2009. Figure 4 provides a histogram for the distribution of the crises episodes over time. The year 2009 stands out as having the most crises. There were also a higher number of crises in the early 1980s and 1990s. This tabulation is consistent with well-known economic and financial crises that have affected the global economy, including the sovereign debt crises of the early 1980s, the Savings and Loans crisis and the Japanese banking crisis of the 1990s.

Identifying the monetary policy stance is more complicated, primarily due to the lack of a common monetary policy instrument across countries and time. In particular, the policy instrument depends on the exchange rate regime. We follow Kaminsky, Reinhart, and Vegh (2004) and use short-term interest rates as the policy instrument. Under flexible exchange rate regimes, short-

\footnotetext{
${ }^{6}$ We also explored two alternative definitions provided by Milesi-Ferretti, Gian, and Razin (2008).
} 
term interest rates characterize monetary policy since changes in money supply influences these rates. However, under predetermined exchange rate regimes, short-term rates are valid monetary policy instruments only if we assume imperfect substitution between domestic and foreign assets. See, for example, Flood and Jeanne (2000) or Lahiri and Vegh (2003). For the choice of short-term rates, we begin with the monetary policy rates, and supplement with the discount or interbank rates. When these series are not available, we rely on short-term Treasury bill rates, and then money market rates.

In addition to short-term interest rates, we also use growth of central banks' domestic credit to proxy for monetary policy. Under flexible exchange rate regimes, central bank domestic credit growth affects the monetary base and short-term rates. Under predetermined exchange rate regimes and perfect substitution between domestic and foreign assets, growth in central bank credit will be offset by an opposite effect in foreign exchange reserves. However, if domestic and foreign assets are imperfect substitutes, an increase in central bank credit will have some effect on the monetary base and short-term interest rates.

Even with good measures of the monetary policy instrument, characterizing the monetary policy stance is not obvious. For the purpose of this study, we define countercyclical policy as a movement in the direction of loosening monetary policy during periods of economic stress. We define a binary indicator variable that takes a value of one if: the policy rate declines in the year of the crisis relative to the previous year or when the central bank's domestic credit growth in the crisis year exceeds that of the previous year and the average rate of the three years prior to the crisis. When the monetary policy rate is not available, we rely on other short-term rates.

We are mindful of the potential imperfections associated with the use of other short-term interest rates to as a measure of monetary policy. Short-term rates can change independent of the true monetary policy rate. For example, risk premia tend to increase during crises, causing some shortterm rates to rise even if policy rates have been lowered. However, in periods of crises, we posit that a decline in short-term rates likely indicates lower monetary policy rates. At the outset, we obtain the policy stance for 980 crisis years, 127 for the advanced economies and 853 for EMEs.

Figure 5 presents the frequency countercyclical monetary policy during crises over time and for the two sets of countries. The figure highlights the contrast between the advanced economies and EMEs. While the advanced economies have traditionally conducted countercyclical monetary policy during crises, it is only in the latter periods that EMEs began to do so. During crises in 
the 1970s, EMEs lowered rates in only about 30 percent of the crises. This fraction has increased steadily, to 70 percent in the most recent decade. During the 2008-2009 global crisis, the fraction rose further, to over 80 percent.

\subsection{Econometric Specification and Data Description}

The econometric model is a more general version of equation (1) used in the previous section.

$$
\operatorname{Pr} o b(C C M P=1)_{i, \tau-1}=\Phi\left(\beta^{\prime} X_{i, \tau-1}\right)
$$

Where $\Phi\left(\beta^{\prime} X_{i, j}\right)=\frac{e^{\beta^{\prime} X_{i, \tau-1}}}{1+e^{\beta^{\prime} X_{i, \tau-1}}} ; X_{i, \tau-1}$ represents a set of explanatory variables that capture a country's ability to conduct countercyclical monetary policy during crises and are measured in the year before the crisis $(\tau-1)$ for each crisis country $i$. The set of independent variables $(X)$ are as defined in the previous section, but measured with a lag. Summary statistics for the independent variables over the 1970-2009 sample period are described in Table 1.

\subsection{Estimation and Results}

\subsubsection{Univariate Analysis}

Table 4 presents the regression results for the univariate model. They are generally similar to those in Table 2.

Macroeconomic Fundamentals and Vulnerability: Strong macroeconomic fundamentals and reduced vulnerability increase the chances of conducting countercyclical monetary policy. A country with pre-crisis inflation in the bottom quartile of the distribution is 62 percent more likely to reduce rates during the crisis. Similarly, countries with the largest amount of foreign exchange reserves (in the top quartile) are about 2.5 times more likely to conduct countercyclical policy. Those with the highest levels of short-term external debt to foreign exchange reserves ratio are less likely to conduct countercyclical policy during crises. The coefficients on the share of short-term external debt, current account surpluses, and government debt have the expected sign but are not statistically significant.

Openness: The next set of results examine the role of openness. Overall, they suggest an important role for openness in a country's ability to conduct countercyclical monetary policy. Countries with highly open capital accounts (top quartile of the distribution) are 45 percent more 
likely to loosen monetary policy during crises. Similarly, those most closed to trade are about 40 percent less likely to loosen monetary policy.

Exchange Rate Regime and Policy Credibility: The coefficient for the exchange rate regime has the expected sign; countries with the most flexible form of exchange rate regime are more likely to loosen monetary policy but the coefficient is not statistically significant. Again, the results for inflation targeting, which also proxies for transparency and credibility of the central bank, are the strongest. They suggest that a country with inflation targeting is nearly 7 times more likely to conduct countercyclical monetary policy than a country without an inflation targeting regime.

Financial Development and Financial Reforms: Both financial development and reforms enhance the ability to conduct countercyclical monetary policy. Countries that have achieved the highest level of financial reforms are more than twice as likely to loosen monetary policy, and those with the most developed financial system are 50 percent more likely to loosen monetary policy.

In sum, these results suggest strong linkages between a country's ability to conduct monetary policy and its macroeconomic fundamentals and vulnerability, its degree of openness, the exchange rate regime and the credibility of the central bank's policy, as well as the degree of financial development and reforms. Judging by the size of the coefficients, inflation targeting appears to be the most important determinant of the ability to conduct countercyclical monetary policy, followed by a high level of financial reforms, large amounts of foreign exchange reserves, and low inflation.

\subsubsection{Multivariate Analysis}

Table 5 presents the odds ratios obtained from the multivariate regression using equation (2). We estimate the model with OxMetrics. It explored 450 models (combinations of regressors), and selected, based on the Akaike Information Criterion, the 12 comparable alternative models reported in columns 1 through 12 of the table.

Macroeconomic Fundamentals and Vulnerability: As found previously, stronger macroeconomic fundamentals and low vulnerability enhance the odds of countercyclical monetary policy. Countries with the lowest pre-crisis rate of inflation are more than twice as likely to lower interest rates during crises. These results are consistent with the prediction from a Taylor rule reaction function. Indeed, in a low inflation environment, monetary authorities can loosen monetary policy to stimulate economic activity without concerns of fueling inflation. We find evidence that higher foreign exchange reserves as a percent of GDP enhance the odds of conducting countercyclical monetary 
policy. Having foreign exchange reserves to cover the external short-term debt is a robust indicator of a country's ability to conduct countercyclical monetary policy. Countries in the lowest quartile of the short-term debt to foreign exchange reserves distribution are roughly twice as likely to conduct countercyclical monetary policy, and the effect appears to be monotonic. The extent to which a country can cover its short-term debt is indeed an important indicator of its solvency in periods of crises when the rollover of debt or issuance of new debt becomes difficult.

Openness: In one of the specifications, we find evidence that financial openness increases the likelihood of countercyclical monetary policy. Countries most open to trade are 50 percent more likely to loosen monetary policy during a crisis. The coefficient for trade openness has the expected sign but it is not statistically significant.

Exchange Rate Regime and Policy Credibility: The coefficient for the exchange rate regime is statistically insignificant. By contrast, as documented previously, inflation targeting remains the most robust predictor of a country's ability to conduct countercyclical monetary policy. Inflation targeters are about 6-to-11 times more likely than non-targeters to loosen monetary policy during a crisis, and this effect is consistently robust across the various alternative models.

Financial Development and Financial Reforms: The coefficient for financial reforms is robust across a number of alternative specifications. Countries with the highest level of financial reforms are roughly 3 times more likely to conduct countercyclical monetary policy. The results for financial development are not significant in a number of cases but, where significant, they are counterintuitive.

\section{Caveats and Robustness Analysis}

In this section, we conduct robustness analysis to assess the importance of some of the assumptions we have made and discuss some possible caveats.

During the analysis, as in Kaminsky, Reinhart, and Vegh (2004), we assume that under imperfect substitution between foreign and domestic assets, short-term interest rates are good monetary policy instruments under predetermined exchange rate regimes. To assess how this assumption affects our results, we restrict the sample to non-pegged exchange rate regimes in the first robustness test. The second test, we restrict the measurement of monetary policy to policy rates and discount rates only-the two most reliable measures-in order to control for the effect of potential imperfections in 
other measures of monetary policy. In the third robustness test, we remove from the sample crises episodes during which policy was acyclical-when interest rates did not change between the pre-crisis year and crisis year. In the last robustness test, we remove from the sample the second of any two crises that occur in consecutive years for the same country to ensure that our results are not driven by a possible doublecounting of the same crisis. The results for these robustness analyses are presented in Table 6, column 1, 2, 3, and 4, respectively. Our main results, highlighting the importance of financial reforms and inflation targeting regimes on a country's ability to conduct countercyclical monetary policy, still hold.

One caveat is whether nominal interest rates (not real interest rates) are the appropriate measure of monetary policy stance. We are unable to measure inflation expectations and formally conduct this robustness analysis. Our study is more concerned with the direction of monetary policy from the standpoint of the central bank and not with the actual policy stance. As such, the use of nominal interest rates is appropriate.

Another caveat pertains to the other nonconventional monetary policy instruments that EMEs often use. In advanced economies with well-functioning financial markets, the main monetary policy instrument consists of open market operations and, to a lesser extent, adjustments to the discount rate and reserve requirement ratios. In EMEs, where financial markets are underdeveloped, monetary policy use other nonconventional instruments such as credit ceilings, and moral suasion. Although this study does not take into account all of the measures of monetary policy, we believe that if data were available, changes in these instruments would generally be consistent with the changes in short-term rates. For example, it is not likely that the central bank will lower short-term interest rates and at the same time raise reserve requirements or lower the credit ceilings.

We further assured that our main results are robust to a number of the caveats mentioned earlier by the consistency between the analysis over the 1970-2009 sample and the 2008-2009 subsample. In the 2008-2009 sub-sample, we have better measures of the monetary policy rates and, hence, rely less on other short-term interest rates as proxies for policy rates. Moreover, fewer countries had pegged exchange rate regimes suggesting that the assumption of imperfect substitution domestic and foreign assets is not as necessary. Finally, one might be concerned about the effect of differences in nature of crises in our sample 1970-2009. Again, we are comforted by the consistency of the results obtained from the two samples. The cross-section analysis that uses 
only the 2008-2009 sub-sample allows us to control for the nature of the crisis and identify the determinants of countercyclical policy through cross-country variations.

\section{Concluding Remarks}

During the recent global financial crisis, a large number of EMEs loosened monetary policy to cushion the effect of the global financial crisis. This was a remarkable departure from previous crisis episodes during which EMEs had to tighten monetary policy. In this study, we explored the factors that enabled this shift in policy stance and find statistically significant linkages between some characteristics of the economies and their ability to conduct countercyclical monetary policy.

The results indicate that stronger macroeconomic fundamentals and reduced vulnerabilities, greater openness to trade and financial flows, financial reforms and the adoption of inflation targeting all facilitated the conduct of countercyclical policy in EMEs. Of these factors, financial reforms and inflation targeting stand out as the most important. Several EMEs adopted inflation targeting since the late 1990s and, over the past decades, EMEs have also reformed their financial sectors. Inflation targeting regimes enhance transparency and flexibility of monetary policy.

By adopting inflation targeting and by implementing financial reforms, EMEs also achieved a greater policy credibility. Indeed, lack of policy credibility is one of the main impediments to EMEs' ability to conduct countercyclical monetary policy. When credibility is fragile, an attempt by the central bank to loosen monetary policy is perceived as a permanent switch to a loose money regime. This perception adversely affects confidence and increases risk premiums demanded by foreign investors. The adoption of inflation targeting helps to dispel these perceptions, as it fosters confidence in monetary policy and anchors inflation expectations. Moreover, inflation targeting has been accompanied by reduced emphasis on exchange rate management, thereby allowing monetary policy to be flexibly geared toward the stabilization of the domestic economy.

We interpret our results to suggest that as long as EMEs maintain strong economic fundamentals, continue to reform their financial markets, and adopt flexible and transparent monetary policy frameworks such as inflation targeting, the conduct of countercyclical policy as an economic stabilization tool will likely be sustainable. The increasing popularity of inflation targeting among EMEs is particularly encouraging in this regard. We are not aware of a country that has adopted inflation targeting and abandoned it out of dissatisfaction, and there appears to be a degree of 
irreversibility in financial reforms, suggesting that the conduct of countercyclical policy could be sustainable.

The increasing ability of EMEs to use monetary policy as a macroeconomic stabilization tool might partly explain the greater resilience of these economies to shocks emanating from the advanced economies despite increasing integration between the two sets of countries. 


\section{References}

Abiad, A. and D. Enrica and T. Thierry (2008). "A New Database of Financial Reforms." IMF Working Paper No. 266.

Aguiar, M., and G. Gopinath (2007). "Emerging Market Business Cycles: The Cycle is the Trendm," Journal of Political Economy, Vol. 115 (1), pp. 69-102.

Alesina, Alberto, and Lawrence H. Summers (1993). "Central Bank Independence and Macroeconomic Performance: Some Comparative Evidence," Journal of Money, Credit and Banking, Vol. 25 (May), pp. 151-62.

Braun, Miguel (2001). "Why is Fiscal Policy Procyclical in Developing Countries?" mimeo, Harvard University.

Calderon, C. and D. Roberto and S. Klaus (2003). "The Role of Credibility in the Cyclical Properties of Macroeconomic Policies in Emerging Economies," Central Bank of Chile Working Paper No. 237.

Callabero, Ricardo (2002). "Emerging Markets' Economics", Mimeo, MIT.

Calvo, Guillermo and Reinhart, Carmen (2002). "Fear of Floating," Quarterly Journal of Economics, Vol. 107, pp. 379-408.

Chinn, Menzie and Hiro, Ito (2006). "A New Measure of Financial Openness," Journal of Comparative Policy Analysis 10(3). September 2008: pp. 307-320.

Devereux, Michael and Lane, Philip (2003). "Understanding Bilateral Exchange Rate Volatility," CEPR Discussion Papers 3518.

Flood, Robert and Jeanne, Olivier (2000). "An Interest Rate Defense of a Fixed Exchange Rate?" IMF Working Paper No. 159.

Frankel, Jeffrey and Rose, Andrew (1996). "Currency Crashes in emerging markets: An empirical treatment." Journal of International Economics, Vol. 41, pp. 351-366.

Gavin, Michael and Perotti, Roberto (1997). "Fiscal Policy in Latin America." NBER Macroeconomics Annual 1997, Vol. 12, pp. 11-72. 
Gupta, Sanjeev and Akitoby, Bernardin and Clements, Benedict and Inchauste Gabriela (2004). "The Cyclical and Long-Term Behavior of Government Expenditures in Developing Countries," IMF Working Paper No. 202.

Hnatkovska, Viktoria and Lahiri Amartya and Vegh, Carlos (2008). "Interest Rates and the Exchange Rate: A Non-Montonic Tale," NBER Working Paper No. 13925.

Ilzetzki, Ethan and Reinhart, Carmen and Rogoff, Kenneth (2011). "Exchange Rate Arrangements Entering the 21st Century: Which Anchor Will Hold?" University of Maryland Working Paper Series.

Kaminsky, Graciela, Reinhart, Carmen and Vegh, Carlos (2004). "When it Rains, it Pours: Procyclical Capital Flows and Macroeconomic Policies," NBER Working Paper No. 10780.

Lahiri A. and C. Vegh (200). "Delaying the Inevitable: Interest Rate Defense and Balance of Payments Crises," Journal of Political Economy 111.

Lane, Philip (2003). "Business Cycles and Macroeconomic Policy in Emerging Market Economies," International Finance, 6 (1), pp. 89-108.

Mendoza, Enrique (2002). "Why Should Emerging Economies Give Up National Currencies: A Case for Institutions Substitution," NBER Working Paper No. 8950.

Milesi-Ferretti, Gian Maria and Razin, Assaf (2008). "Sharp Reductions in Current Account Deficits: An Empirical Analysis," European Economic Review, Vol. 24, Issues 3-5, pp. 897-908.

Mishkin, Frederic (2010). "Monetary Policy Strategy: Lessons From the Crisis," in Monetary Policy Revisited: Lessons from the Crisis (European Central Bank: Frankfurt, forthcoming).

Riascos, Alvaro and Vegh, Carlos (2003). "Procyclical Government Spending in Developing Countries: The Role of Capital Market Imperfections," UCLA Working Paper.

Talvi, Ernesto and Vegh, Carlos (2004). "Tax Base Variability and Procyclical Fiscal Policy in Developing Countries," Journal of Development Economics, Vol. 78 pp. 156-190.

Yakhin, Yossi (2008). "Financial Integration and Cyclicality of Monetary Policy in Small Open Economies," Monaster Center for Economic Research Discussion Paper No. 08-11. 


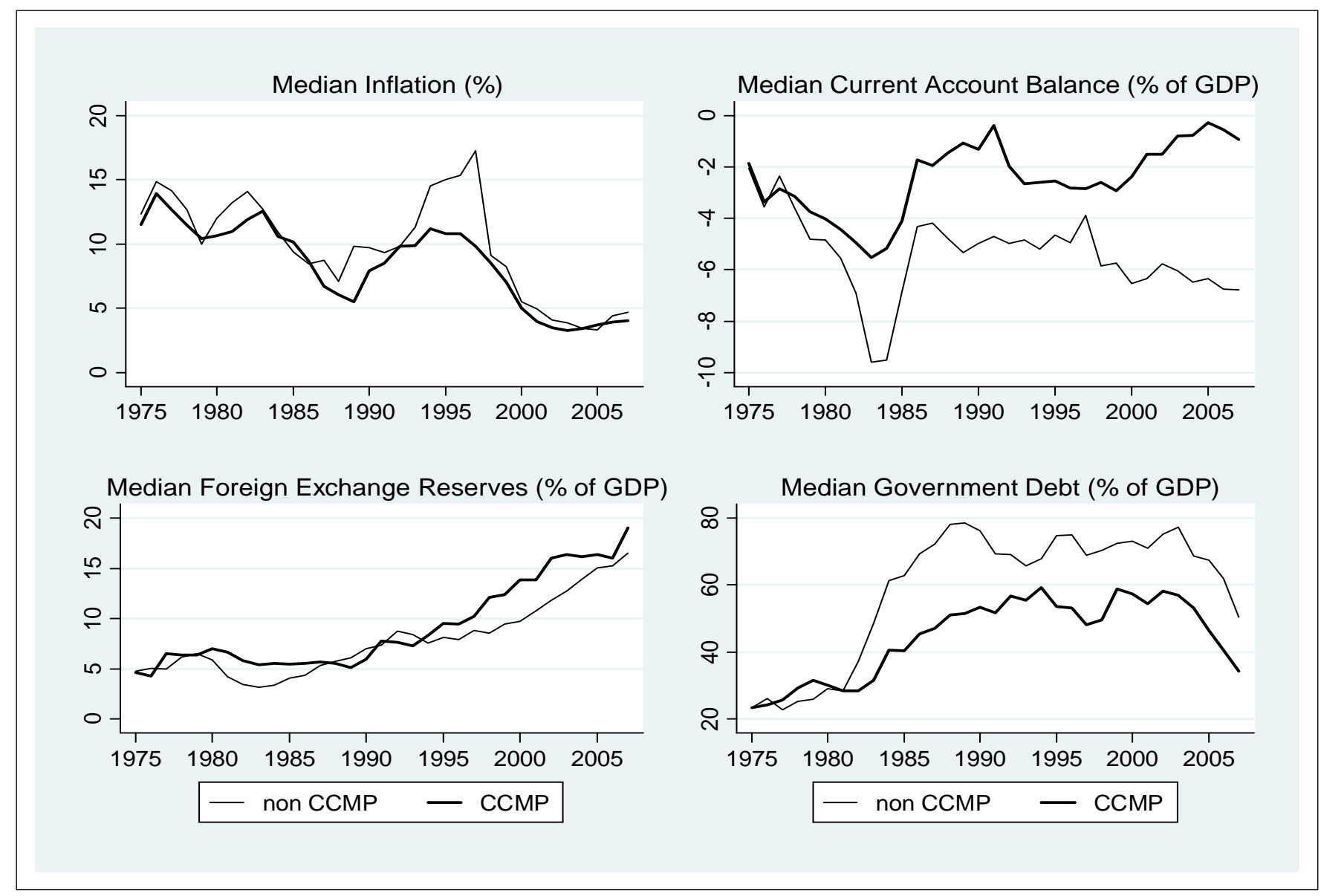

Figure 1: Timeline of Macroeconomic Variables by Monetary Policy Behavior during the 2008-2009 Crisis 


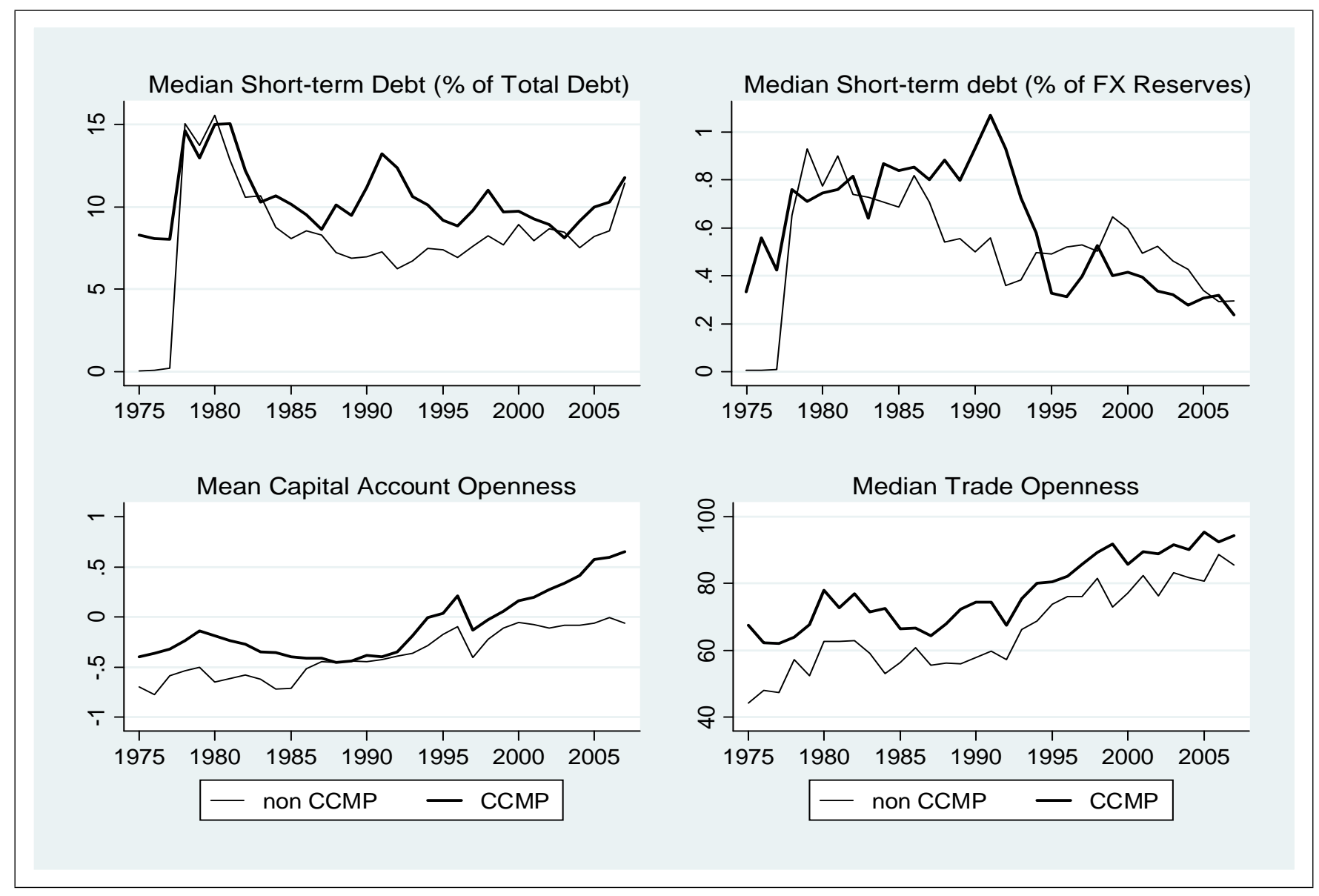

Figure 2: Timeline of Macroeconomic Variables by Monetary Policy Behavior during the 2008-2009 Crisis 


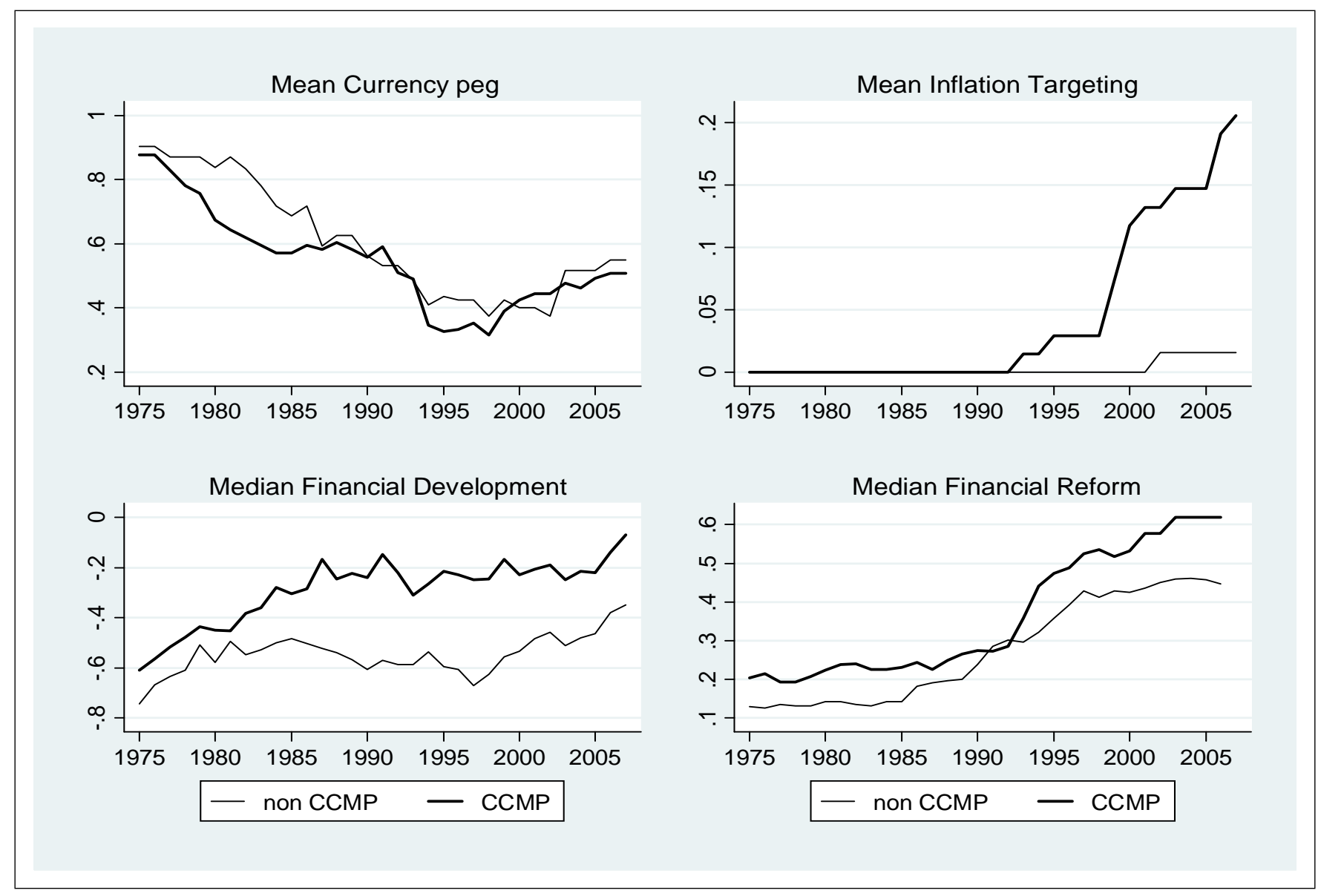

Figure 3: Timeline of Macroeconomic Variables by Monetary Policy Behavior during the 2008-2009 Crisis 


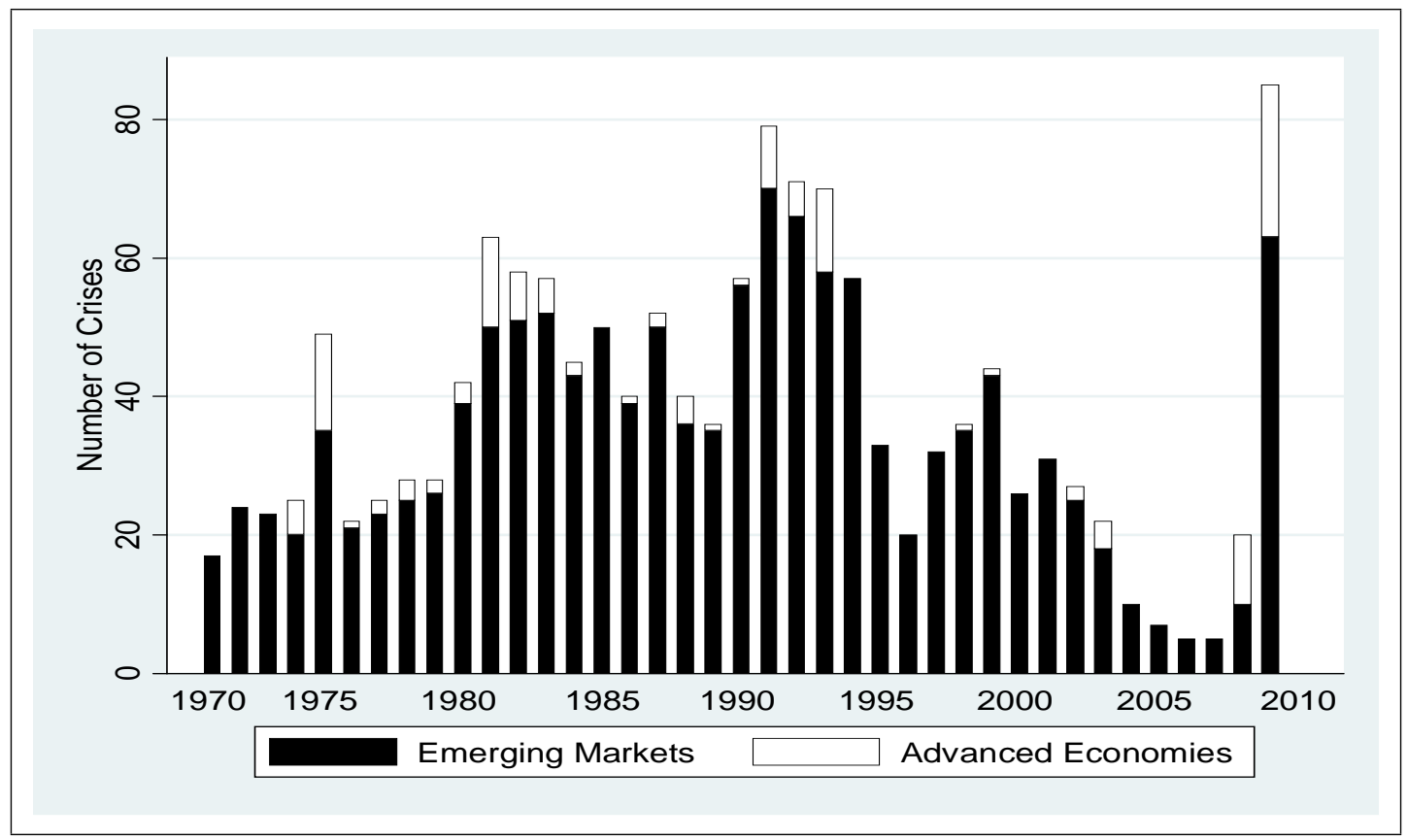

Figure 4: Frequency of Financial and Economic Crises: 1970-2009.

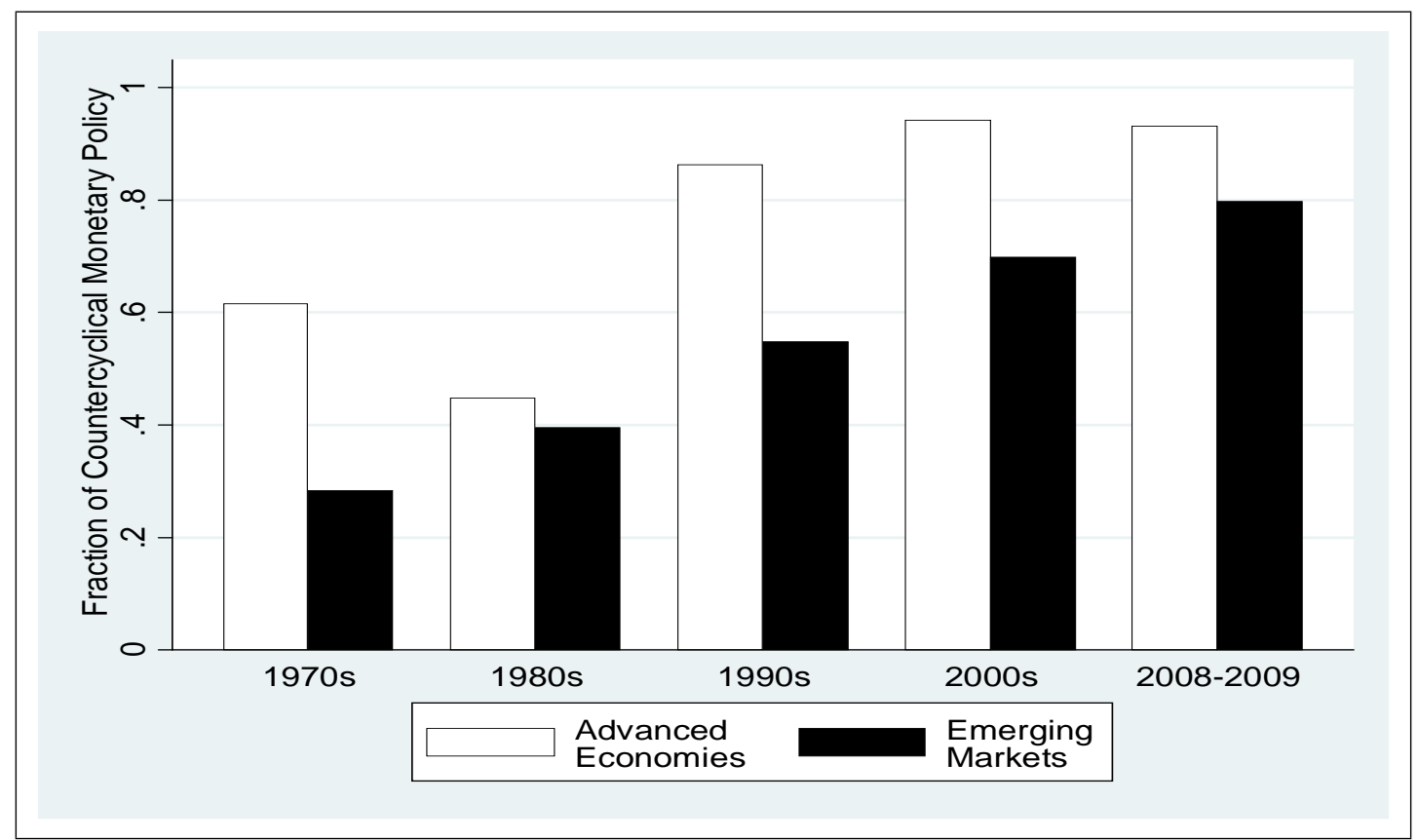

Figure 5: Fraction of Crises during which Advanced and Emerging Market Economies Conducted Countercyclical Monetary Policy. 


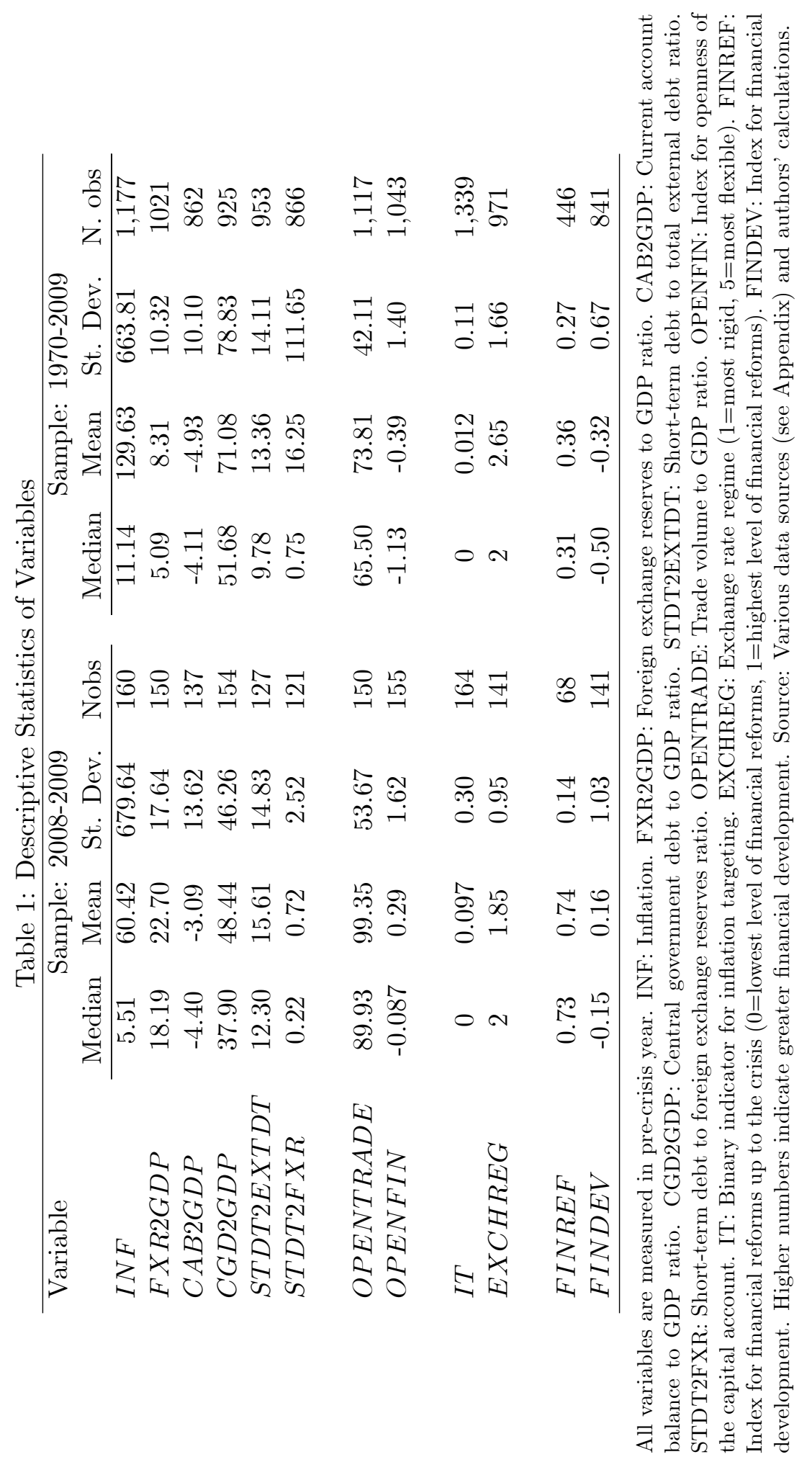




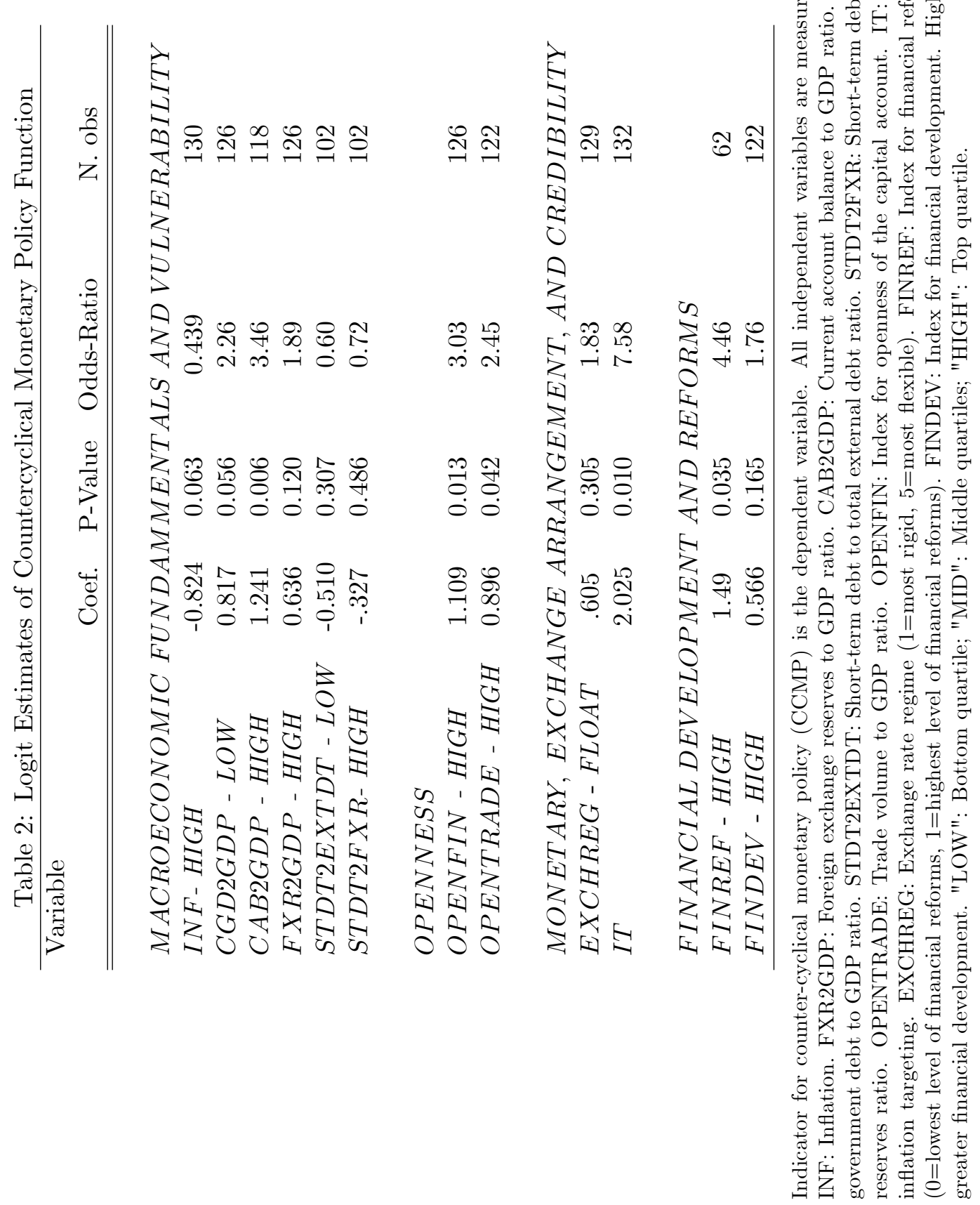

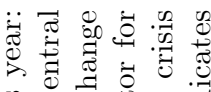

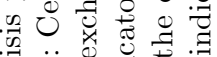

iे

议

$\exists$ 웡

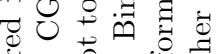

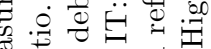

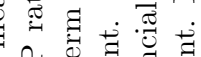

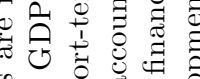

후

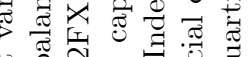

우의

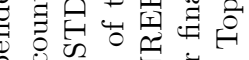

政 . 


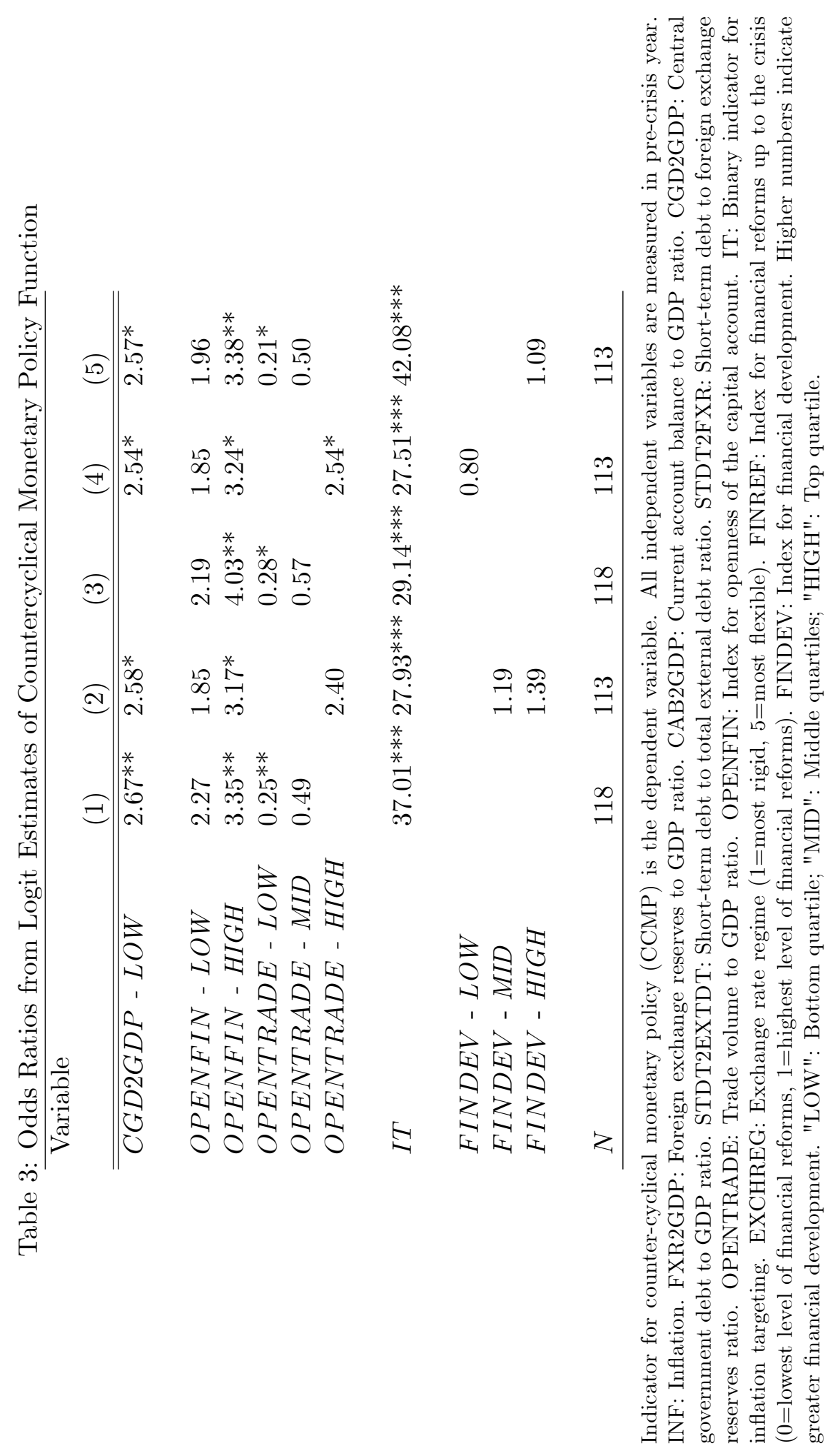




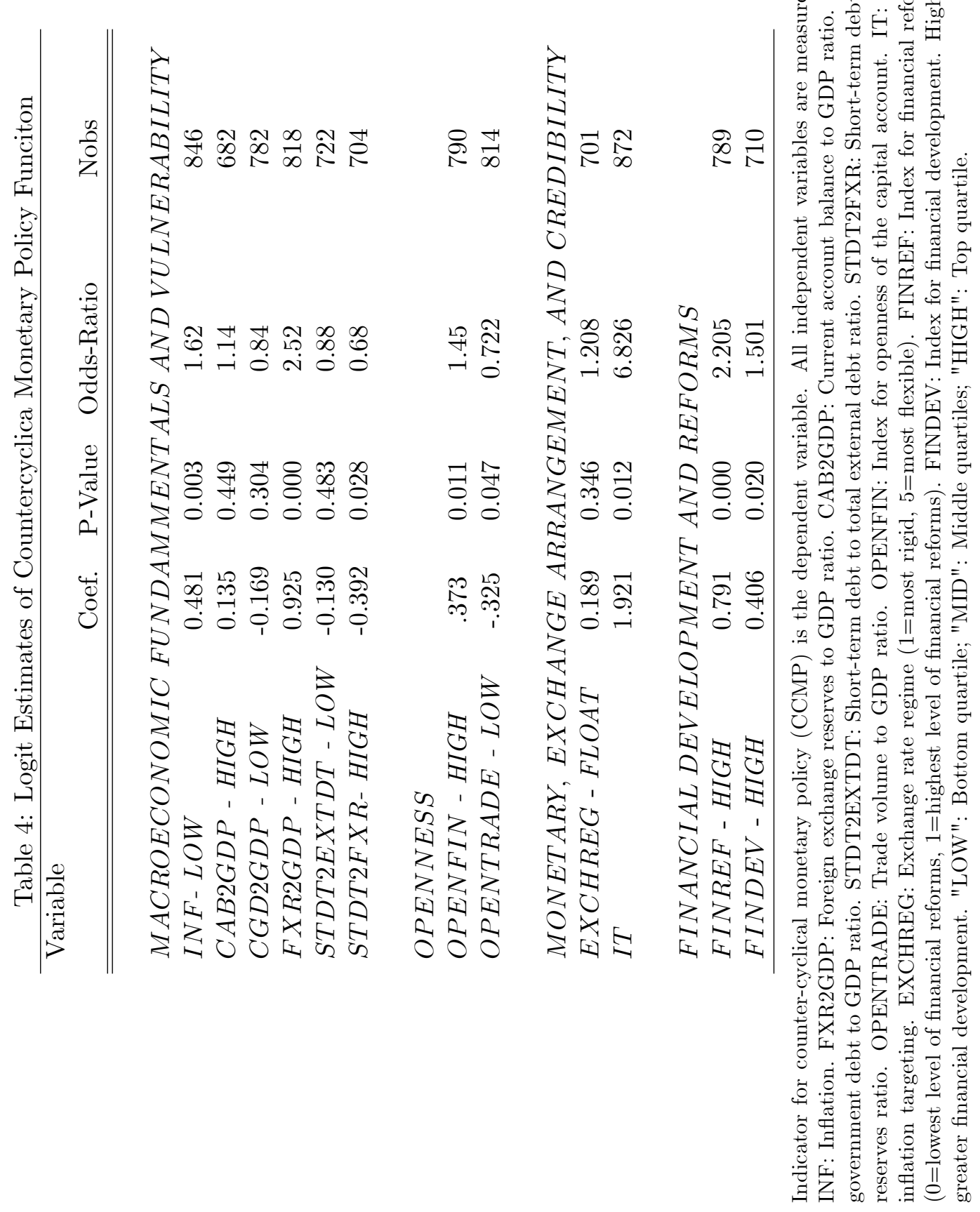




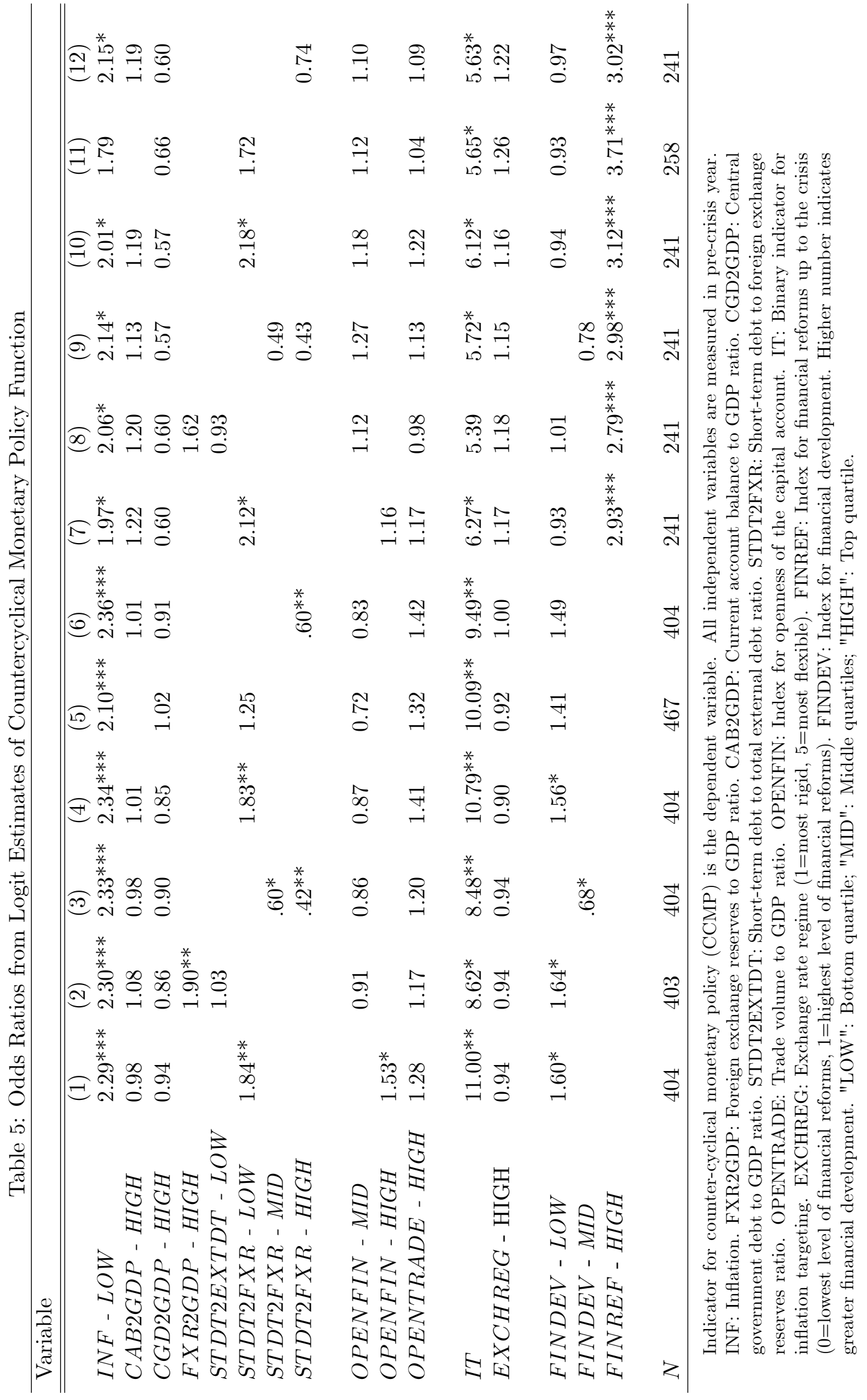




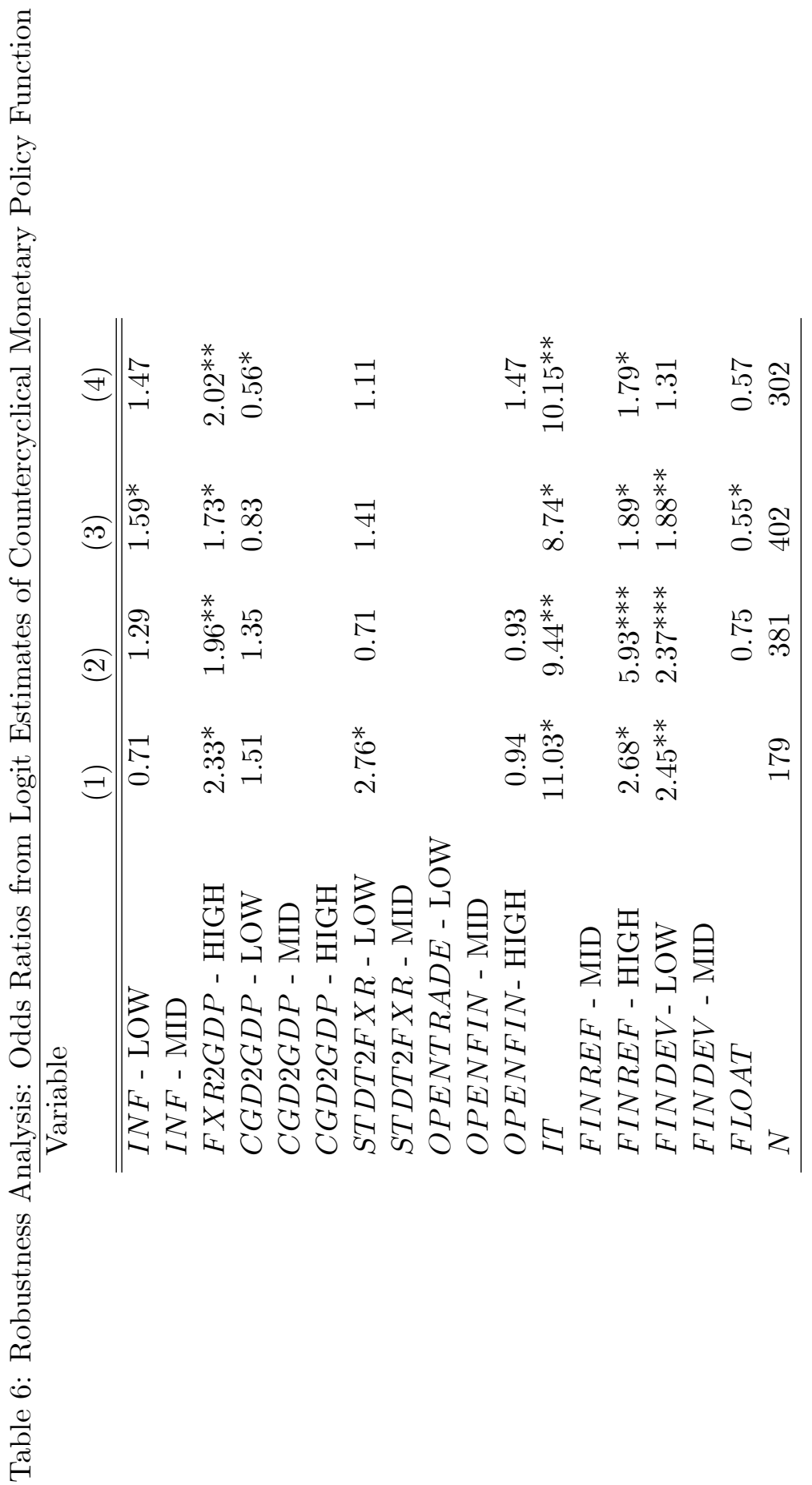

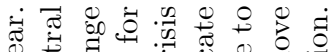

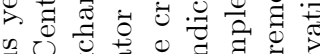

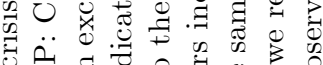
ن. 岤 쿠웜 ठ०

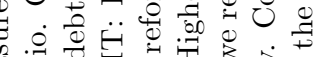

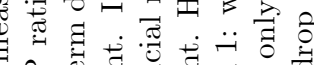

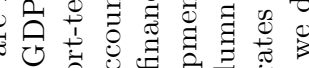

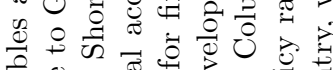

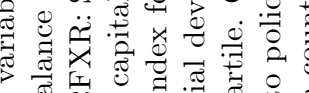

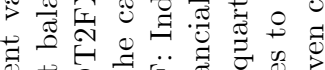

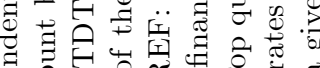
过设

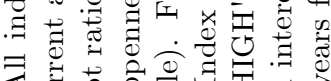

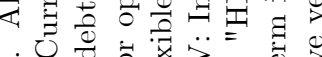

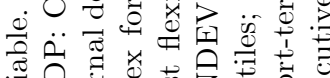

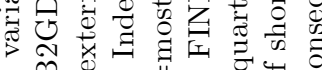
Ұ

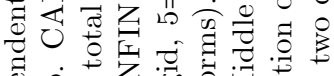

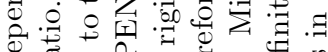
ष्ञ 过守.

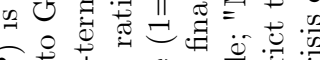

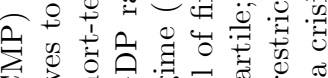
ठ 萬

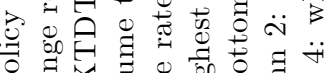

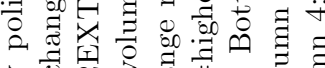
궀

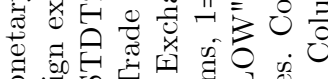

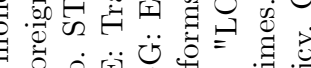

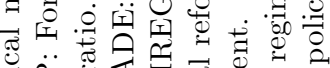

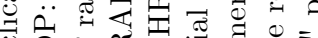

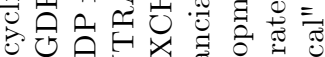

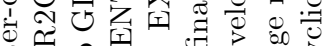

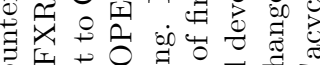
5.

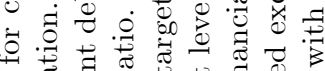

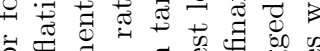

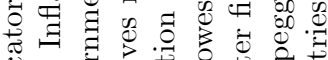

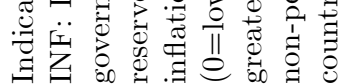

